Eurasian Journal of Business and Economics 2016, 9 (17), 125-151.

\title{
SMEs' Wealth Creation Model of an Emerging Economy
}

\author{
Olalekan Usiobaifo ASIKHIA*
}

\begin{abstract}
This article synthesizes the evidence on SMEs' wealth creation in an emerging economy, paying particular attention to human resource/expertise, technology adoption, innovation and creativity, unit economies, organizational infrastructure and strategy as determinants of SMEs' wealth creation. A survey of 581 Nigerian SMEs was conducted and the data was analysed and tested using multiple regression and structural equation modelling. The findings revealed Human resource/CEOs expertise as the highest contributory factor to wealth creation within the firm in the industrial and the commercial sectors. The relevant domains were modelled and relevant policy adjustments were suggested.
\end{abstract}

Keywords: Wealth creation Model, Commercial sector, Industrial sector, Emerging economy, Nigeria.

JEL Code Classification: M20, L26

UDC: 330.322

DOI: https://doi.org/10.17015/ejbe.2016.017.08

\footnotetext{
* Professor of Marketing and Strategic Management, Graduate School of Business Leadership, University of South Africa, South Africa. E-mail olalekanasikhia@yahoo.com, asikhou@unisa.ac.za 


\section{Introduction}

Studies that aim to investigate the wealth creation capacity of Small and Medium scale Enterprises (SMEs) from the point of view of the Chief Executive Officers (CEO) who are seen as the decision makers have become increasingly important as most governments pursue economic policies that can alleviate poverty in their nations (Alia 2014; Bello \& Ivanov 2014; Goedhuys \& Sleuwaegen, 2010; Hamilton, 2012). Many of these studies focused on developed and transition economies (Enderle, 2005; Santos-Paulino, 2012, Pitelis \& Vasilaros, 2009), with little attention paid to the developing countries where poverty is predominant (Aigbokhan, 2008; Dugguh, 2013; Kiggundu, 2002; Robson \& Obehg, 2008; Shaffer, 2008)

Despite strong theoretical foundations used to explain SME performance (i.e. the resource based view, the contingency theory, absorptive capability and organization learning theories as well as entrepreneurial orientations) and findings reported from various research studies on factors that have been associated with SME wealth creation, limited research is available to present empirically tested models that provide an integrated perspective on the relationship between SME performance antecedents and wealth created by SMEs (Asikhia \& Jansen van Rensburg, 2015; Barney, 1991; Cohen \& Levinthal ,1990; Covin \& Stevin, 1991; Enderle, 2005; Grant, 1996a, 1996b; Njanja, Ogutu, \& Pellissier, 2012; Mintzberg, 1984; Lawrence \& Lorsch, 1967; Lumpkin \& Dess, 2001; Penrose, 1959; Pitelis \& Vasilaros, 2009; Wernerfelt, 1995; Zahra \& George, 2002).

This article reports and makes valuable contributions of the empirical findings of the determinants of SME wealth creation capacity in Nigeria.

\section{Theoretical Foundations}

\subsection{SMEs Wealth Creation}

There is little denial that the study of SMEs' wealth creation has not received enough attention in developing countries in recent years (Asikhia \& Jansen van Rensburg 2015; Enderle 2005; Pitelis \& Vasilaros 2009). The creation of wealth from individual perspective requires savings, investments and willingness to forgo consumption in the present for the sake of increased well-being in the future. Wealth creation furthermore requires the identification, finance and implementation of socially profitable investments through a continuous learning process (Wilkerson \& Williams 2011). At the firm level, wealth creation is seen as a product of technology and innovation (Pitelis \& Vasilaros 2009; Enderle 2005). To create wealth is therefore to make something new or better. At an individual level, the Chief Executive Officers of the SMEs are believed to be critical element in the decision making, strategic direction and general management of the firms, this study thus assumed that allocation of the resources of the firm also depend on them hence they form the unit of analysis of the study, the decision of the firm is seen as their decisions. Organizations that have capacity to create and grow wealth 
or its values are those who consistently innovate, invest wisely and adapt quickly to the ever-changing social, demographic, technological, economic and political trends and forces bearing on their industry (Pitelis and Vasilaros 2009). Firms that fail to keep up do not always survive whereas firms that succeed provide superior returns for their investors, better jobs for their employees and the best value for their customers.

The study on which this article reports is aimed to empirically test an integrated theoretical model which has been used to explain organizational performance in previous studies. One of the earlier theories that explained wealth was Penrose (1959) resource based view (RBV). This theory noted that wealth could be created through firm growth influenced by the extent of the firm resources. It advanced that the capacity of firms to generate and sustain competitive advantage depend on their unique set of resources and capabilities. While suggesting the usefulness of RBV in entrepreneurship, Alvarez and Busenitz (2001) adopted the RBV to include the cognitive abilities of individual entrepreneurs. Hence, they considered individual-specific resources required to facilitate the recognition of new opportunities and the assembling of resources for the venture. Similarly, it is believed that SMEs mostly build their competitive advantage on internal elements supported by resources and capabilities difficult to imitate by larger competitors. Aragon-Sanchez and Sanchez-Martin (2007) found that SMEs' competitiveness is based on elements such as technological innovation, flexibility and organizational design and human resource management. Additionally, Chetty and Wilson (2003) highlight the need for social ties and external networks to create opportunities for alliances and corporation. Gassmann and Keupp (2007) affirm that SMEs mostly achieve competitive advantage through experimental knowledge in line with the knowledge based view- an outgrowth of the RBV (Gray and Gray 2012; Grant 1996). Such knowledge can be used to identify entrepreneurial opportunities, develop creative or novel internal solutions or external offerings. The knowledge based view theory thus provides a good conceptual analytical framework for SMEs.

\section{Hypotheses Development}

\subsection{Human Resource}

Jansen, Curseu, Vermeulen, Geurts, and Gibcus (2013) affirm that the effectiveness of decision depends on the characteristics of the decision-makers. Supporting this view, Garavan, Watson, Carbery, and O'Brien (2015), establish a positive relationship between the human resource/ leadership expertise of the ownermanagers of SMEs with performance. The leadership expertise are said to be positively related to education (Bryan 2006; Jayawarna, Jones, and Macpherson 2014; Devins and Johnson, 2003), skills (Adekunle, 2013; Barbero, Casillas, and Feldman, 2011, Lukic, 2014) and experience (Camelo-Ordaz, Fernandez-Alles, RuizNavarro, and Sousa-Ginel, 2012; O' Cass and Sok, 2014), It is thus hypothesized that: 
H1: Chief Executive Officers' expertise comprising education, skills and experience would relate positively with SMEs' wealth creation.

\subsection{Technology Adoption}

Asikhia and Jansen van Rensburg (2015) posit that technological capability could be measured by information acquisition and information use and relates positively with wealth creation. In affirming this, Zhang, Macpherson and Jones (2006) assert that managerial capabilities and mechanisms for accessing knowledge from external sources are critical for SMEs' technological emancipation and innovation performance. And technology adoption was found to be related to information acquisition which in turn has a positive relationship with business performance (Chirico, 2008; De Clerca and Arenius 2006; Peltier, Zhao, and Schibrowsky 2012) and information use which also related positively with business success (Rice, Liao, Galvin, and Martin, 2015; De Clerca, Dimoy, and Thongpapanl 2015). It is hypothesized that:

H2: Chief Executive Officers' Technology adoption, information acquisition and information use would relate positively with SMEs' wealth creation.

\subsection{Innovation and Creativity}

Innovation and creativity have been found to be part of the critical activities of the SMEs for enhanced performance (Aslan \& Elci, 2009; Hadjimanolis \& Dickson 2000; Love and Roper, 2015; Skiltere and Jesilevska, 2013). In a large scale survey of small firms in Scotland and Northern England, a positive relationship between novel product innovation and employment growth was established (Freel \& Robson 2004). Also, Spencer, Kirchhoff and White (2008) affirm that innovation is a source of wealth creation. Different studies allude to the fact that licensed intellectual property (Barbero, Casillas, \& Feldman, 2011; Gallego, Rubalcaba, \& Hipp 2013; Skiltere \& Jesilevska, 2013), degree of customers and employees involvement (Batra, Sharma, Dixit, \& Vohra, 2015; De Jong \& Vermeulen, 2006), Network and Collaboration (Shaw, 2006; Whittaker, Fath, \& Fiedler 2014) relate positively with innovation and creativity as well as business performance. It is thus hypothesized that:

H3: SMEs' Innovation and creativity, licensed intellectual property, degree of customers and employees involvement, and Network and Collaboration are positively related with SMEs'Wealth Creation.

\subsection{Unit Cost Economies}

The unit cost economies comprised the economies of scale and economies of scope. Economies of scale results when an increase in output leads to a reduction in average cost. At a constant capacity, the managerial cost of increasing output can be expected to be low. Moreover, economies of scope may arise from either cost complementary that may be guaranteed between different output categories 
or the spreading of common costs over an expanded product mix (Tovar and Wall 2012). Illueca and Lafuente (2003) note that there is a direct correlation between firm size and productivity growth, mainly due to technical change and catching-up effect thus inferring that scale effect has a positive relationship with productivity. It is hypothesized that:

H4: SMEs' unit economies, economies of scale and associate and economies of scope positively relate with SMEs' Wealth creation

\subsection{Organizational Infrastructure}

Various researchers have identified the major components of organizational infrastructure as structure, routines and processes as well as established the links with performance (Clark 1996; Makadok 2001; Kraus et al. 2011, Ray et al. 2004; Robbins 2000). Others like; Freel and Robson (2004) assert that growing sales and productivity are positively associated with incremental process in service firms; while Messeghem (2003) reveals the relevance of SMEs' organizational structure alignment with strategy. Therefore:

H5: SMEs' organizational Infrastructure, structure, processes and routines, structural flexibility, agility and degree of integration associate positively with SMEs' Wealth creation.

\subsection{Strategy}

Entrepreneurs of small organizations conduct early search for strategic fit in the market and the environment and persist in their search for better fit in the market (Majumdar, 2008).Several researches expressed the relationship between SMEs' strategic stance and performance. For example: Escriba-Esteve, Sanchez-Peinado and Sanchez-Peinado (2008) establish positive and significant relationship between SMEs' strategic orientation and performance; Maney, Manoloya, Harkins, and Gyoshey (2014) find that strategic intensity is positively related with performance; firms that deviate from pure cost leadership or differentiation and achieve a balance on both dimensions report superior performance; they further report that strategic intensity may act as a mediator of the relationship between strategic type and performance. Asikhia and Jansen van Rensburg (2015) identify the main SMEs' strategies as; product differentiation, strategic entrepreneurship, niche strategy, cost parity, opportunity seeking abilities, advantage seeking abilities and growth orientation. It is thus hypothesized that:

H6: SMEs' strategies, product differentiation, strategic entrepreneurship, niche strategy, cost parity, opportunity seeking abilities and advantage seeking abilities associate positively with SMEs' wealth creation.

The regressional model to be evaluated are:

Hence the aggregate model is: 
$W C R=b 0+b 1 H R+b 2 T E C H+b 3 I C+b 4 U C E+b 5 O I F+b 6 S T R A+e$

Each of the six models evaluated are:

$$
\begin{aligned}
& \mathrm{HR}=\mathrm{b0}+\mathrm{b} 1 \mathrm{Ed}+\mathrm{b} 2 \mathrm{Ex}+\mathrm{b} 3 \mathrm{As}+\mathrm{e} \\
& \mathrm{TECH}=\mathrm{b} 0+\mathrm{b} 1 \mathrm{la}+\mathrm{b} 2 \mathrm{lu}+\mathrm{e} \\
& \mathrm{IC}=\mathrm{b} 0+\mathrm{b} 1 \mathrm{Lip}+\mathrm{b} 2 \mathrm{Cei}+\mathrm{b} 3 \mathrm{Nc}+\mathrm{e} \\
& \mathrm{UCE}=\mathrm{b} 0+\mathrm{b} 1 \mathrm{Esc}+\mathrm{b} 2 \mathrm{Eos}+\mathrm{e} \\
& \text { OIF=b0 +b1Os + b2Fle + b3 Agi + b4 Doi +e } \\
& \text { STRA=b0 +b1 Pd + b2Se+b3 Ose + b4 Ase+b5Ns + b6Cp +e }
\end{aligned}
$$

Where:

WCR $=$ Wealth Created, $\mathrm{HR}=$ Human Resource, $\mathrm{TECH}=$ Technology Adoption, $\mathrm{IC}=$ Innovation and Creativity, UCE= Unit Cost Economies, OIF= Organizational Infrastructure, STRA= Strategy, Ed= Educational qualification, Ex= Experience, As=Ability and skills, la=Information acquisition, lu= Information use, Lip=Licensed intellectual property, $\mathrm{Ce}=$ degree of customer and employee integration, $\mathrm{Nc}=$ Network and collaboration, Esc= Economies of scope, Eos= Economies of Scale, Os=Organizational structure, Fle= structural Flexibity, Agi=structural Agility, Doi= Degree of integration, $\mathrm{Pd}=$ Product differentiation, Se=Strategic entrepreneurship, Ose=Opportunity seeking, Ase= Advantage seeking, Ns= Niche strategy and $\mathrm{Cp}=$ Cost parity.

\section{Research Method}

\subsection{Research Context}

Successive governments in Nigeria have since independence in 1960, pursued the goal of structural changes without much success. The growth dynamics have been propelled by the exploration and exploitation of natural resources and primary products. Initially, the industrial sector through agricultural activities, driven by the demand for food and cash crops production was at the center of the growth process, contributing 54.7 per cent to the GDP during the 1960s (World Bank Report 1979). The second decade of independence saw the emergence of the oil industry as the main driver of growth. Since then, the economy has gone through series of boom burst cycles of the oil industry. Government expenditure dependent on oil revenues have more or less informed the pace of growth of the economy. Looking back, it is clear that the economy has not actually performed to its full potential particularly in the face of its rising population (Asikhia 2015).

In light of the poor performance of the Nigerian economy and the inability of various policies to provide visible changes in both micro and macro-economic variables of the economy (for example; the recent World Bank Report of 2014 rated the economy as the largest in Africa with a resource base of $\$ 510$ Billion), the 
country is still the first amongst the tenth poorest nations in the world. Studies by UNIDO-Nigeria, (2012), show that small and medium Enterprises (SMEs) have the propensity to drive the Nigerian Economy. Data also reveals that currently Nigerians' firms employ over 31 million Nigerians. SMEs account for over $80 \%$ of enterprises that employ about $75 \%$ of the Nigeria's total workforce.

Over the years, the Nigerian Government has taken various steps (including monetary, fiscal and industrial policy measures) to promote the development of Small and Medium Scale Enterprises (SMEs). Specifically, the Government has been active in the following areas: funding and setting up of industrial estates to reduce overhead costs; establishing specialized financial institutions, including the Small Scale Industry Credit Scheme (SSICSs), Nigerian Industrial Development Bank (NIDB), Nigerian Bank for Commerce and Industry (NBCI) to provide long-term credit, facilitating and guaranteeing external finance by the World Bank, African Development Bank and other international financial institutions; facilitating the establishment of the National Directorate of Employment (NDE), which also initiated the setting up of new SMEs, establishment of the National Economic Reconstruction Fund (NERFUND) (to provide medium to long-term local and foreign loans for small, and medium scale businesses) and provision of technical training and advisory services through the Industrial Development Centers (Adejugbe 2002; Orewa 2002; Emordi 2008).

The present study thus evaluated the wealth creation model of these SMEs and investigated the determinants of the wealth created. Small and Medium scale Enterprises (SMEs) is defined in line with the Central Bank of Nigeria's (2012) definition of SMEs as those firms with fewer than 100 employees and an annual turnover of not less than N500, 000.

\subsection{Sample and Data Collection}

The study is based on survey responses from five hundred and eighty one (581) Nigerian SMEs' CEOs (out of one thousand initially sampled, making $58.1 \%$ response rate) who dully completed a questionnaire in face-to-face interviews between February 1 and May 2, 2015. The questionnaires were administered by Babcock University doctoral students in the department of Business Administration and Marketing. Due to lack of single public register of SMEs in Nigeria (Asikhia 2010; Dugguh 2013), the survey population was drawn from multiple sources of business listings (Small and Medium Scale Development Agency of Nigeria (SMEDAN), Nigerian Small and Medium Scale Association (NASMA) and CAC Business directory). The CEOs who completed the questionnaire were located in the three main regions of Nigeria as follows; North (Sokoto and Niger states), East (Ebonyi and Abia states), West (Ogun and Lagos).Two states are purposively selected from each of the regions based on their poverty level, government support and degree of commercial activities. These variables tend to be critical in ensuring uniformity and spread in the selection (Asikhia 2010). Non- response bias 
tests were carried out by using core information such as the number employees and business activity from the firms which collected the questionnaire but did not respond. Following Bullock's (2003) and Obeng, Robson, and Haugh's (2012) approach there was no evidence of response bias at the 10 percent level.

\subsection{Measures}

The variables and their measures were drawn from the SMEs' wealth creation model of Asikhia and Jansen van Rensburg (2015) supported by the reviewed theoretical and conceptual underpinnings (as shown in figure 1). Although this is the first time the model would be tested but the five-point likert type scale and items used were drawn from existing works (See table 1).

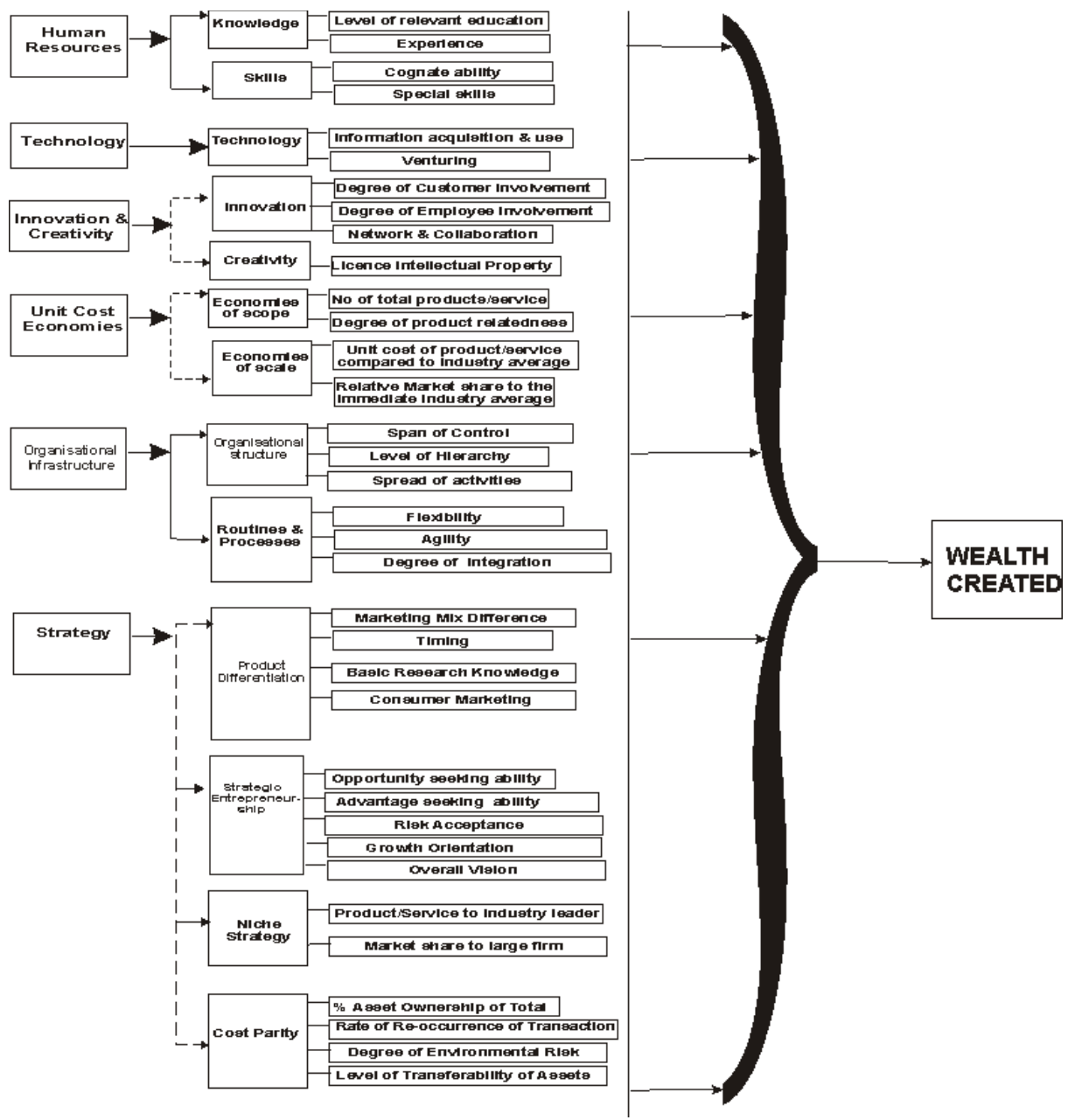

Figure 1. SMEs Wealth Creation Model

Source: Asikhia and Jansen van Rensburg (2015) 
Table 1. Descriptive Information of the developed Instrument

\begin{tabular}{|c|c|c|c|}
\hline Scale & $\begin{array}{l}\text { No of } \\
\text { Items }\end{array}$ & Measures & Reference \\
\hline $\begin{array}{l}\text { Wealth } \\
\text { Created }\end{array}$ & 8 & $\begin{array}{l}\text { Increase in income, } \\
\text { Increase in physical assets, } \\
\text { Ability to meet family and other social } \\
\text { responsibilities, Investments in } \\
\text { business, Other Private investments, } \\
\text { Product and service delivery } \\
\text { expansion, Increase in working capital } \\
\text { and Enhancement of intellectual } \\
\text { capability }\end{array}$ & $\begin{array}{l}\text { Chang, Chen, Lin, \& Gao } \\
\text { (2012); } \\
\text { Chiang \& Yan, 2011; Enderle, } \\
\text { (2005); } \\
\text { Obeng et. al (2012), Pender } \\
\text { et al. (2012); } \\
\text { Pitelis \& Vasilaros, (2009). }\end{array}$ \\
\hline $\begin{array}{l}\text { Human } \\
\text { resources }\end{array}$ & 10 & $\begin{array}{l}\text { Level of relevant education and extent } \\
\text { of impact on the business, Measure of } \\
\text { related Experience and extent of } \\
\text { relationship with the business; } \\
\text { Cognate abilities and special skills, a } \\
\text { measure of skills before the start of } \\
\text { business, current skills and relative } \\
\text { importance of the cognate abilities } \\
\text { and skills to the business presently. }\end{array}$ & $\begin{array}{l}\text { Barbero et. al. (2011); } \\
\text { Garavan et.al. (2015); } \\
\text { Jayawarna, et. al. (2014); O' } \\
\text { Cass \& Sok (2014), Lukic } \\
\text { (2014) }\end{array}$ \\
\hline Technology & 8 & $\begin{array}{l}\text { Information acquisition that involves } \\
\text { knowledge about industry players, } \\
\text { new information, rate of use of } \\
\text { information. }\end{array}$ & $\begin{array}{l}\text { Chirico (2008); } \\
\text { De Clerca \& Arenius, 2006; } \\
\text { Peltier, et.al.(2012); } \\
\text { Rice et.al.(2015) } \\
\text { Zhang et. al.(2006) } \\
\end{array}$ \\
\hline $\begin{array}{l}\text { Innovation } \\
\text { and } \\
\text { Creativity }\end{array}$ & 10 & $\begin{array}{l}\text { Venturing; measure of investments in } \\
\text { other areas of business, Licensed } \\
\text { intellectual property, } \\
\text { Degree of customers' participation in } \\
\text { decision making, Degree of employee } \\
\text { participation in decision making and } \\
\text { Extent of Network and collaboration. }\end{array}$ & $\begin{array}{l}\text { Batra et. al. (2015); } \\
\text { Bharadwai \& Menon } \\
\text { (2000);Changet.al. (2012); } \\
\text { Gallego et. al. } \\
\text { (2013); Hadjimanolis \& } \\
\text { Dickson (2000); Love \& } \\
\text { Roper (2015); Spencer et.al. } \\
\text { (2008); Thorgren et. al. } \\
\text { (2012); } \\
\text { Whittaker et.al.(2014), } \\
\text { Skiltere \& Jesilevska (2013), } \\
\text { Aslan \& Elci(2009) }\end{array}$ \\
\hline $\begin{array}{l}\text { Unit cost } \\
\text { economies }\end{array}$ & 10 & $\begin{array}{l}\text { Economies of scale; extent to which } \\
\text { bulk purchasing as impacted on the } \\
\text { business and cost of operation; and } \\
\text { Economies of Scope ; extent to which } \\
\text { extended line of product } \\
\text { and service delivery has facilitated } \\
\text { materials and operational facilities } \\
\text { sharing to minimize cost of production } \\
\text { or cost of doing business. }\end{array}$ & $\begin{array}{l}\text { Illueca \& Lafuente (2003); } \\
\text { Nooteboom (2007); } \\
\text { Tovar and Wall (2012). }\end{array}$ \\
\hline
\end{tabular}


Table 1 (cont). Descriptive Information of the developed Instrument

\begin{tabular}{|c|c|c|c|}
\hline Scale & $\begin{array}{l}\text { No of } \\
\text { Items }\end{array}$ & Measures & Reference \\
\hline $\begin{array}{l}\text { Organizational } \\
\text { infrastructure }\end{array}$ & 12 & $\begin{array}{l}\text { Measures of Organizational } \\
\text { structure Span of control, Level of } \\
\text { hierarchy and } \\
\text { Spread of activities; Routines and } \\
\text { process: flexibility, agility and } \\
\text { Degree of integration, }\end{array}$ & $\begin{array}{l}\text { Alpkan et.al.(2007); } \\
\text { Analoni, and Karami (2003); } \\
\text { De Clerca et.al. (2015); } \\
\text { Hornsby and Kuratko } \\
\text { (2003); } \\
\text { Kraus et al. (2011); } \\
\text { March and Olsen (1976); } \\
\text { Teece et al.(1994); } \\
\text { Vyakarnam \& Handelberg } \\
\text { (2005); } \\
\text { Weick (1976) }\end{array}$ \\
\hline Strategy & 18 & 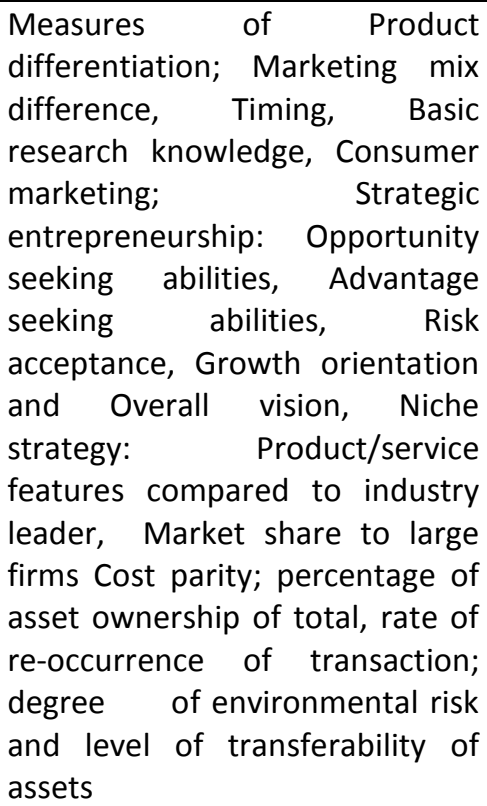 & $\begin{array}{l}\text { Barney \& Hesterley, } \\
\text { 2006; } \\
\text { Bello \& Ivanov, 2014; } \\
\text { Jaquier, 2003; } \\
\text { Majumdar, 2008; } \\
\text { Maney, et. al., 2014 } \\
\text { Minarik, 2007; } \\
\text { Porter, 1996 } \\
\text { Ireland, Hitt \& Sirmon, } \\
\text { 2003; } \\
\text { Ireland \& Webb, 2007; } \\
\text { Kalantaridis, 2009; } \\
\text { Kraus et.al., 2011; } \\
\text { Kyrgidou, 2008; } \\
\text { Luke, Kearins \& } \\
\text { Verreynne, 2011) } \\
\text { Bamford et al. 1997) } \\
\text { Basco, 2014; Garfamy, } \\
\text { 2012). }\end{array}$ \\
\hline
\end{tabular}

The details of all constructs are presented in Appendix A. The Cronbach's alpha was above 0.70 .

Controls: It has been pointed out that value creation may vary with firm size and age (Pender et al. 2012; Pitelis and Vasilaros 2009). We thus controlled the wealth creation capacity of the firms with firm size and age.

\subsection{Measurement Model and Validity}

Confirmatory factor analysis (CFA) was conducted to test the validity of all constructs individually. All items loaded significantly on their respective latent construct with item loadings greater than 0.5 , thus revealing convergent validity 
(Liu et al. 2003). The CFA was conducted on a six-factor model comprising human resource components, technology, innovation \& creativity, unit cost economies, organizational infrastructure and firm strategy. Overall the model showed good fit indices: chi square (minimum discrepancy)/degrees of freedom (CMIN/DF) $=1.54$; Comparative Fit Index $(\mathrm{CFI})=0.91$; Root Mean Square Error of Approximation $($ RMSEA $)=0.60$. This model was then compared with other constrained models which restricted each pair of constructs' correlation to 1 . Model fit worsened in all models, thus indicating the six-factor model to be the best model.

\subsection{Potential Sources of Bias}

Some measures were adopted to reduce the biases in the survey method. For instance, we requested the CEOs or the most senior executive to complete the questionnaire. Non- response bias was tested by comparing the early and the late respondents. The key constructs of the instrument were contrasted for those respondents who filled their responses in the earlier visit with those of the later visits. We did not find any significant differences because none of the correlations were more than 0.7. The Durbin-Watson test (2.28) indicated that there was no Multi-collinearity. Harman's single factor test was conducted to test for common method variance. When all items were loaded on different constructs through factor analysis, multiple factors with eigen values above 1 was obtained. Latent factor test using Analysis of Moment Structures (AMOS) was also conducted. When all items were allowed to load on a single latent factor, the model fit did not change significantly (CMIN/DF=1.51; $C F I=0.92$, RMSEA=0.05).

\section{Results and Discussions}

Table 2 shows the relevant demographic factors of the CEOs and SMEs. There are more males (65.10\%) than females (34.90\%).

The age bracket reveal greater percentage of younger CEOs ( $<50$ years $=58.86 \%)$ compared to $41.14 \%$ that are older than 50years. Majority of the firms are averagely young $70.39 \%$ are between 5 -15years of operation and about half of the SMEs have <=N15m operational fund. Most of the operators are educated with qualification above School certificate $(75.38 \%)$ and $64.89 \%$ of the CEOs have over 11years of working experience.

Table 3 shows the summary statistics and correlation matrix, and there was no evidence of multi-collinearity.

It was observed that all the variables have relationships ranging from moderate to strong relationships with the wealth created as shown in table 3 and figure 2.

Results in table 4 shows that participations in industrial sector of the economy has been greatly influenced by gender while ages of the firms affect the ability to create wealth in both industrial and commercial sectors of the economy. There are much of less educated CEOs in the industrial sector than the commercial sector. 
However, more of the educated CEOs contributed to wealth creation in the commercial sector. Holders of University degrees contributed to wealth created in both sectors. This is consistent with the view of Bryan (2006) and Camelo-Ordaz et. al ( 2012).

\section{Table 2. Analysis of respondents' demographic factor}

\begin{tabular}{|c|c|c|}
\hline Variables & Frequency & Percentage \\
\hline \multicolumn{3}{|l|}{ Gender } \\
\hline Male & 378 & 65.10 \\
\hline Female & 203 & 34.90 \\
\hline \multicolumn{3}{|l|}{ CEO's Age } \\
\hline Between 20-30years & 46 & 7.91 \\
\hline Between 31-40years & 122 & 21.00 \\
\hline Between 41-50years & 174 & 29.95 \\
\hline Above 50 years & 239 & 41.14 \\
\hline \multicolumn{3}{|l|}{ Firm Age } \\
\hline Between 5-10years & 208 & 35.80 \\
\hline Between 11-15years & 201 & 34.59 \\
\hline Between 16-20years & 168 & 28.91 \\
\hline Above 20 years & 4 & 0.70 \\
\hline \multicolumn{3}{|l|}{ Firm Size } \\
\hline Between N500,00 and N5m & 26 & 4.47 \\
\hline Between N5m-N10m & 120 & 20.66 \\
\hline Between N10m-N15m & 134 & 23.07 \\
\hline Between N15m-N20m & 244 & 41.99 \\
\hline Above $\mathrm{N} 20 \mathrm{~m}$ & 57 & 9.81 \\
\hline \multicolumn{3}{|l|}{ Educational Qualification } \\
\hline Primary School certificate & 22 & 3.79 \\
\hline SSCE/GCE & 121 & 20.83 \\
\hline NCE & 110 & 18.93 \\
\hline HND & 176 & 30.29 \\
\hline BSC & 128 & 22.03 \\
\hline Others (PGD, MSc, Phd) & 24 & 4.13 \\
\hline \multicolumn{3}{|l|}{ CEO's Years of Experience } \\
\hline Between 0-10years & 204 & 35.11 \\
\hline Between 11-20years & 202 & 34.77 \\
\hline Between 21-30years & 170 & 29.26 \\
\hline Above 30 years & 5 & 0.86 \\
\hline \multicolumn{3}{|l|}{ Industry and Sectors } \\
\hline Industrial & 254 & 43.7 \\
\hline Commercial & 327 & 56.3 \\
\hline
\end{tabular}




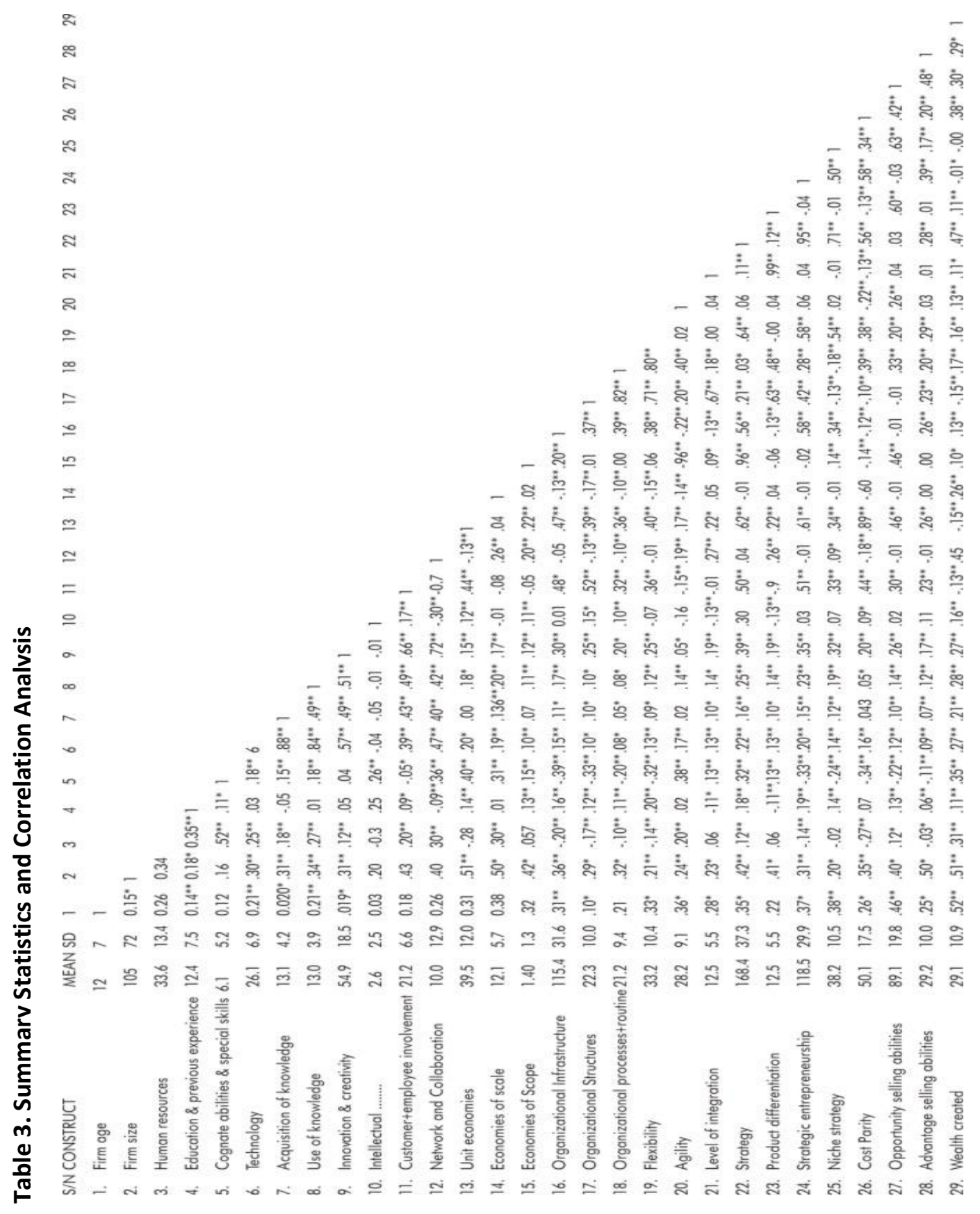




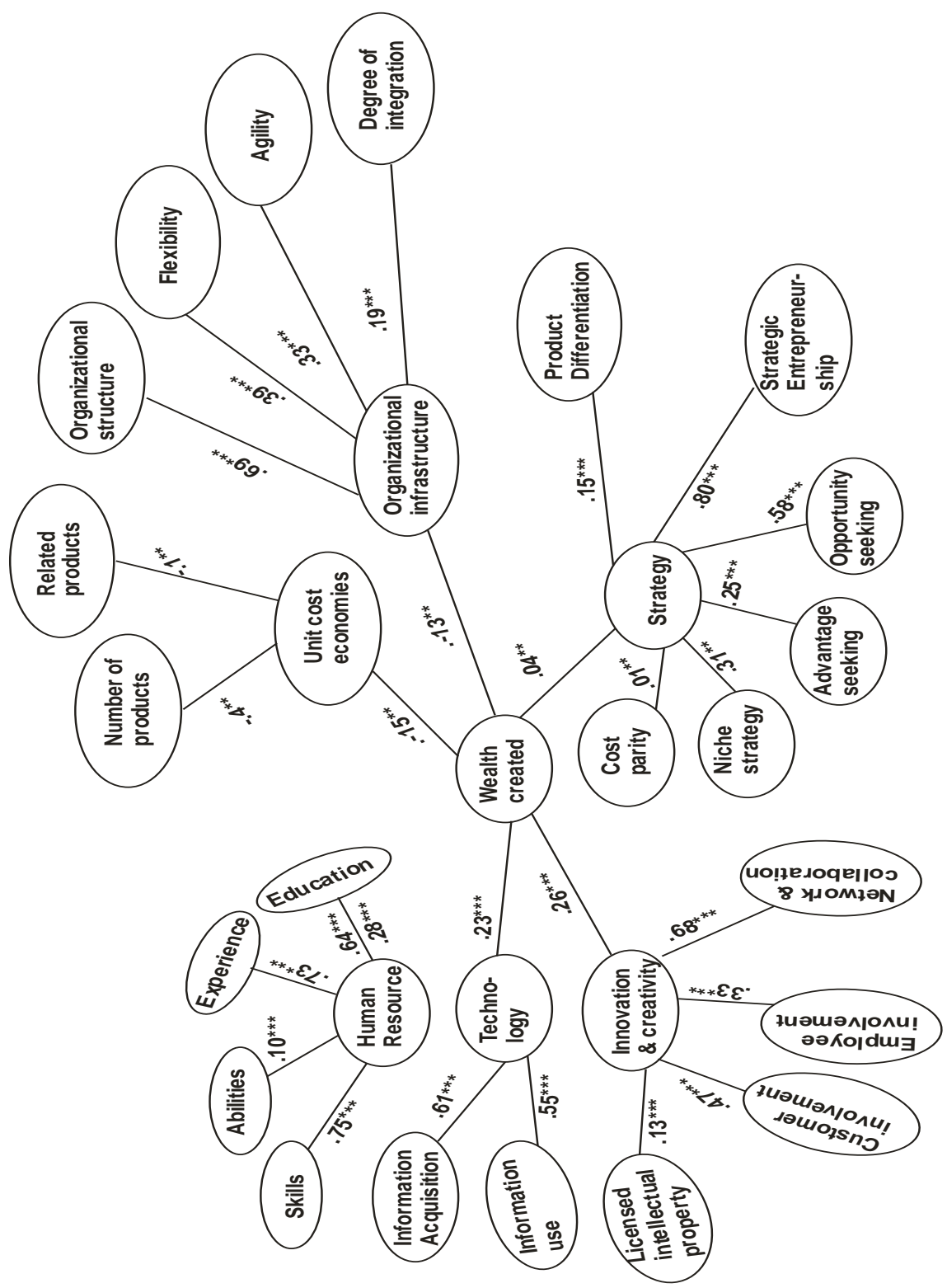

Figure 2. Structural Equation Modeling: Path Dependencies of the variables

Notes: ${ }^{*}=\mathrm{P}<0.05 * *=\mathrm{P}<0.01 * * *=\mathrm{p}<0.001$ 


\begin{tabular}{|c|c|c|c|}
\hline$S / N$ & Indicators & Industrial & Commercial \\
\hline 1 & Gender & $-8.772 * *(16.205)$ & $-4.225(3.666)$ \\
\hline 2 & Firm Age & $-2.831 * *(13.717)$ & $-2.94(13.929)$ \\
\hline 3 & School Certificate & $3.960 * *(9.817)$ & $-0.321(2.110)$ \\
\hline 4 & College of Education & $-0.182(1.989)$ & $4.266 * *(5.782)$ \\
\hline 5 & Polytechnic & $2.114 * *(4.629)$ & $-0.192(1.541)$ \\
\hline 6 & University & $2.994 * *(4.148)$ & $3.892 * *(5.115)$ \\
\hline 7 & Previous Experience & $4.120 * *(6.152)$ & $3.678 * *(5.253)$ \\
\hline 8 & Turnover (Firm Sales) & $5.915^{* *}(8.821)$ & $-2.781(7.552)$ \\
\hline 9 & Human Resource & $4.523 * *(9.011)$ & $3.110 * *(5.153)$ \\
\hline 10 & Technology Adoption & $6.001 *(7.135)$ & $-1.251(2.001)$ \\
\hline 11 & Innovation and Creativity & $5.211 *(7.825)$ & $-2.612(2.089)$ \\
\hline 12 & Unit Cost Economies & $4.332 *(8.342)$ & $-3.315(1.865)$ \\
\hline 13 & Organizational Infrastructure & $2.212 *(4.668)$ & $-0.112(2.354)$ \\
\hline 14 & Strategy & $3.005 *(6.882)$ & $-1.586(2.331)$ \\
\hline \multicolumn{2}{|c|}{ Constant } & $19.827 *(4.884)$ & $10.771 *(3.221)$ \\
\hline \multicolumn{2}{|c|}{ R-Square } & 0.675 & 0.330 \\
\hline \multicolumn{2}{|c|}{$\mathrm{F}$} & $5.655^{*}$ & $4.090^{*}$ \\
\hline \multicolumn{2}{|c|}{$\mathrm{N}$} & 161 & 420 \\
\hline
\end{tabular}

*Significant at $0.05 * *$ Significant at 0.01

As for relevance of education and experience in firm growth, human resource is vital for both sectors in relation to the wealth being created, however, technology adoption, innovation and creativity, unit cost economies, organizational infrastructure and strategy contributed significantly to wealth in the industrial sector than commercial sector. Overall, $67.5 \%$ of the wealth created was from the industrial sector.

\subsection{Human Resource}

The first model denotes the human resource model with the human resource element/CEO's expertise being statistically significant at both 0.05 and 0.01 levels of significance.

Wealth created by the firm $\left(r=0.58^{* *}\right)$ and $\mathrm{R}$-square= .28 indicating that $28 \%$ variation in SMEs' wealth created was caused by the CEO's expertise as shown in table 5. This is the highest contributing variable in the wealth creation model of the firms. The sub variables of operators' level of education, previous experience, cognate abilities and special skills related well with wealth creation $\left(0.64 *, 0.73^{* *}\right.$, $\left.0.75^{* *}\right)$, all significant at 0.05 level of significance. Hence, hypotheses 1 is supported. These support the findings of the previous studies (Barbero et al., 2011; Jayawarna et al., 2014; Garavan et al., 2015; Rosli \& Mahmood 2013) that linked educational qualification and skills to different organizational performance indices and contradicts the Kfindings of Rauch, Frese, and Utsch (2005). Most of the studies which have found positive relationships between educational qualification 
and performance indicators did not consider cognate skills and special abilities. The strength of the present study's findings is derived from the inclusion of cognate skills and special abilities.

Table 5. Regression Analysis (Dependent Variable: Wealth Created)

\begin{tabular}{|c|c|c|c|c|c|c|}
\hline Model & 1 & 2 & 3 & 4 & 5 & 6 \\
\hline Firm Age & 0.01 & 0.01 & 0.01 & 0.00 & .00 & .00 \\
\hline Firm Size & -.04 & .03 & .02 & .02 & .03 & .02 \\
\hline \multicolumn{7}{|l|}{ Human resources } \\
\hline Education & $.64^{*}$ & & & & & \\
\hline Experience & $.73^{* *}$ & & & & & \\
\hline Abilities\& skills & $.75^{* *}$ & & & & & \\
\hline \multicolumn{7}{|l|}{ Technology } \\
\hline Information acquisition & & $.61^{* *}$ & & & & \\
\hline Information use & & $.55^{* *}$ & & & & \\
\hline \multicolumn{7}{|l|}{ Innovation \& creativity } \\
\hline Licensed intellectual property & & & $.02 * *$ & & & \\
\hline Customer\& Employee Involvement & & & $.09 * *$ & & & \\
\hline Network \& collaboration & & & $.16^{* *}$ & & & \\
\hline \multicolumn{7}{|l|}{ Unit cost economies } \\
\hline Economies of Scope & & & & $.06 * *$ & & \\
\hline Economies of Scale & & & & $.01^{* *}$ & & \\
\hline \multicolumn{7}{|l|}{ Organizational infrastructure } \\
\hline Organizational structure & & & & & $.03 * *$ & \\
\hline Flexibility & & & & & $.02 * *$ & \\
\hline Agility & & & & & $.01 * *$ & \\
\hline Degree of integration & & & & & $.01^{*}$ & \\
\hline \multicolumn{7}{|l|}{ Strategy } \\
\hline Product differentiation & & & & & & $.01^{*}$ \\
\hline Strategic entrepreneurship & & & & & & $.01^{*}$ \\
\hline Opportunity seeking & & & & & & $.01^{*}$ \\
\hline Advantage seeking & & & & & & $.01^{*}$ \\
\hline Niche strategy & & & & & & $.01 *$ \\
\hline Cost parity & & & & & & $.01 * *$ \\
\hline Adjusted R-square & $.28 * *$ & $.13^{* *}$ & $.14^{* *}$ & $.16^{* *}$ & $.14^{*}$ & $.13^{* *}$ \\
\hline Model f & 47.47 & 31.99 & 40.37 & 11.62 & 17.09 & 13.77 \\
\hline
\end{tabular}

\subsection{Technology Adoption}

The second model is of the technology adoption, comprising information acquisition and use. They all have positive and statistical relationship and path dependencies with wealth creation as shown in table 5 and figure 2, thus supporting the hypothesis 2. $\left(r=0.23^{* *}, 0.61^{* *}, 0.55^{* *}\right)$. SMEs' technology adoption relates positively with wealth creation $\left(r=0.23^{* *}\right)$ and $\mathrm{R}$-square $=0.13$, indicating that $13 \%$ of the wealth created variation are traceable to technology. This reveals a lower value of contribution compared to human resource, typical of emerging economy which weakens competitiveness of the firms internationally. 
The acquisition and use of technology have significant relation with wealth created. The finding of this study corroborated the outcome of the work of Bako (1991), Rayport and Sviokia (1995), Peltier, Zhao, and Schibrowsky (2012), De Clerca, Dimoy, and Thongpapanl (2015), Hilmersson (2014).While Liu et al (2015) as well as the philosophical underpinnings of RBV of Penrose (1959) sees knowledge as an intangible resource from which organization can build competitive advantage.

\subsection{Innovation and Creativity}

The next model is innovation and creativity. The results in table 5 also show positive but weak association between the licensed intellectual property and wealth creation as well as customer and employee involvement and wealth creation $(r=0.02 * *, 0.09 * *)$. While innovation and creativity has a positive and significant association with wealth creation $\left(r=0.18^{* *}\right)$. The $\mathrm{R}$-square is 0.14 showing that $14 \%$ of the variation in wealth created is caused by the innovation and creativity activities of the SMEs. This result supports the conclusion drawn in previous research that innovativeness relates positively with firm performance (Chang, Chen, Lin, and Gao 2012; Casillas and Moreno 2010; Love and Roper 2015; Lumpkin and Dess 2001; Spencer, Kirchhoff, and White 2008) but the relationships are weak, indicating that less wealth was created through innovation and creativity. However, hypothesis 3 is supported.

\subsection{Unit Cost Economies}

There is a statistically positive but weak associations between; the Unit cost economies and wealth creation $\left(r=0.08^{* *}\right)$, economies of scope and wealth created $\left(r=0.06^{* *}\right)$; economies of scale and wealth creation $\left(r=0.01^{* *}\right)$ thus, supporting hypothesis $\mathrm{H} 4$. R-square is 0.16 , indicating that $16 \%$ of the variation in wealth created is caused by unit cost economies. This result may be premised on the fact that most SMEs rarely take full advantage of economies of scale and scope because of limited resources. The unit cost economies as an aggregate of economies of scale and scope also show that the economy of scale has stronger relationship with wealth creation than economy of scope. This may be due to frequency of use of the method by the operators based on level of operation which was found to affect their level of adoption of cost parity as strategy for competition. This result is supported by Kraus et al (2011), who observed that SMEs hardly achieve cost advantage because they lack some unit cost economies.

\subsection{Organizational Infrastructure}

The fifth model revealed statistically positive but weak association between the organizational infrastructure and wealth creation $\left(r=0.05^{* *}\right)$. Similarly organizational structure $\left(r=0.03^{* *}\right)$, flexibility $\left(r=0.02^{* *}\right)$, agility $\left(r=0.01^{* *}\right)$ and degree of integration $(r=.01 *)$ associated positively with wealth creation, so hypotheses $\mathrm{H} 15-\mathrm{H} 20$ were supported. R-square $=0.14$ indicating that $14 \%$ of the variations in wealth creation of the SMEs were traceable to the organizational 
infrastructure. This is consistent with the view of Clark (1996), De Clerca, Dimoy, and Thongpapanl (2015), Messeghem (2003), Ray et al (2004) and Vyakarnam and Handelberg (2005) that capabilities and competencies that are capable of achieving competitive advantage in operations are premised on the organizational infrastructure, but the fact that the association was a weak one is a pointer to the simplicity required of the SMEs' organizational infrastructure.

\subsection{Strategy}

The last model identified the relationship of the different strategies adopted with wealth created by the SMEs. There was positive but weak relationship that was statistically significant between strategy and wealth created $\left(r=0.03^{* *}\right)$. The product differentiation and cost parity were statistically significant $\left(r=0.01^{*}\right.$, $\left.0.01^{* *}\right)$ and strategic entrepreneurship and niche strategy are $\left(r=0.01^{*}, 0.01^{*}\right)$. However, most of the strategies record stronger and significant relationships in the path dependencies analysis (figure 2; product differentiation, $r=0.15^{* *}$, strategic entrepreneurship, $r=0.80 * * *$, niche strategy, $r=0.31^{* *}$ ). Thus hypotheses $21-27$ are supported. Drawn from the structural equation modeling result, the most important of all the strategies is strategic entrepreneurship $\left(r=0.80^{* * *}\right)$, followed by the Niche strategy $\left(r=0.31^{* *}\right)$, then product differentiation strategy $\left(r=0.15^{* *}\right)$ and finally the cost parity $\left(r=0.01^{* *}\right)$. This corroborates the assertion of Engelen, Gupta, Strenger and Brettel (2015) and Gupta and Batra (2015). Overall model result show that $13 \%$ of the variation in wealth created was due to the strategy adopted by the SMEs. This result corroborate the finding of Maney, Manoloya, Harkins, and Gyoshey (2014) that strategic intensity is positively related to performance; firms that deviate from pure cost leadership or differentiation and try to achieve a balance on both dimensions. Such balance is observed in the $r$ values for product differentiation $\left(r=0.15^{* *}\right)$ and cost parity $\left(r=0.01^{* *}\right)$. EscribaEsteve et al. (2008) establish positive and significant relationship between SMEs' strategic orientation and performance. Also established is the positive and strong relationships between strategic entrepreneurship and two of its components measured (i.e. Opportunity seeking; $r=0.58^{* * *}$; Advantage seeking, $r=0.25^{* * *}$, results are significant at $0.001,0.01$ and 0.05$)$ this also aligns with the findings of Jain and Ali (2012).

Hence the aggregate model is:

$$
\begin{aligned}
& W C R=b_{0}+b_{1} H R+b_{2} \text { TECH }+b_{3} I C+b_{4} \text { UCE }+b_{5} \text { OIF }+b_{6} S T R A+e \\
& W C R=56.8+.28 H R+.13 T E C H+.14 I C+.16 \text { UCE +.14OIF + .13STRA }
\end{aligned}
$$

Each of the six models evaluated are:

$$
\begin{aligned}
& H R=b_{0}+b_{1} E d+b_{2} E x+b_{3} A s+e \\
& H R=47.47+.64 E d+.73 E x+.75 \text { As } \\
& T E C H=b_{0}+b_{1} l a+b_{2} l u+e
\end{aligned}
$$




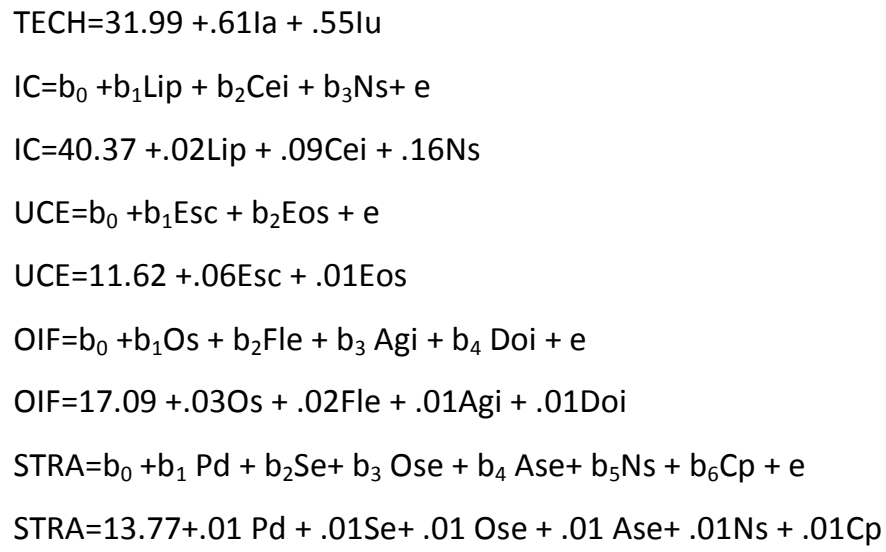

\section{Policy Implications}

It is important to note that the Nigerian government has done a lot to encourage the SMEs in the country and this has been translated to enhanced contribution to the industrial base of the nation as observed in this study. However, a lot needed to be done to further encourage the participation of the SMEs in this sector in the area of facilitation of technological innovation and creativity whose contribution to the wealth created was low comparatively. Enhanced protection of the SMEs to encourage indigenous innovation and creativity to thrive may be one of the ways out because undue exposure to foreign competition at the early stages of new innovation and creativity could kill such adventure.

The fact that the service sector contributed much less to the wealth created and yet has greater presence of the educated CEOs is worrisome. Hence, the need for government to organize workshops that could enlighten them so as to bridge the gap between similar services outside the country apart from providing more enabling environment which serves as the framework for effective service delivery thus providing a level playing ground with similar businesses outside the country.

Finally, government may need to resuscitate Small Medium Enterprises Development Agency of Nigeria (SMEDAN) to help the SMEs in international environmental scanning exercise that would facilitate acquisition of relevant and effective information which could also enhance global positioning and material sourcing that are cost effective.

\section{Conclusion}

This study's analysis of the primary data gathered directly from 581 small and medium scale enterprises of chief executive officers in Nigeria has developed and tested a wealth creation model. An empirical test of the six domains of SMEs' wealth creation was carried out. The results support several statistically significant 
relationships between the variables of each domain and wealth created. The data of this study offer encouragement to policy makers by rejecting the notion that SMEs wealth creation could not be explained from firm-level theory. We found that the most important factor that determines SMEs wealth creation was human resource. And each of the variables of measure scored high in contributing to the wealth created by firms: these are education, cognate experience, abilities and special skills. This could also explain why firms' age was an important moderator in the wealth creation model. The study thus contradicts previous studies that found a negative relationship between experience and firm growth. Hence, the results of our study are consistent with Jovanovic's learning perspective of firm growth. In terms of policy implication in Africa, the results suggest that wealth would be more created by firms with highly educated CEOs with special skills. The government may need to encourage more graduate apprenticeship schemes that could birth new firms and would have high propensity of creating wealth.

The firm size is found to relate positively with wealth creation. This result contradicts the theory of a negative relationship between firm size and growth as well as the view that small firms are founded with suboptimal size and therefore, grow quickly to reach efficient size. It confirmed other studies that found that larger firms grow faster than smaller firms (Frazer 2005; Obeng et al. 2012; Teal, 1998) and thereby supports the RBT of firm growth.

Technology, innovation and creativity are associated with wealth creation amongst the SMEs in Nigeria. The adoption of new technology as well as innovation and creativity help SMEs to face competition and achieve competitive advantage. This finding was consistent with earlier studies (Bakos 1991; Casillas and Moreno 2009; Lumpkin and Dess 2001; Rayport and Sviokla 1995). The Unit cost economies associates positively with wealth creation and the path dependencies were negative. It showed that more wealth was created at a lower cost of operations and that cost parity associated positively with wealth creation.

Organizational infrastructure and strategy are important variables to wealth creation. Organizational infrastructure associated positively with wealth creation but the path dependencies showed a negative trend which inferred that simplicity rather than complex structure is needed for effective wealth creation by the SMEs. The different strategies related significantly with wealth created by the firms. However strategic entrepreneurship, Niche strategy and product differentiation are most prominent.

In conclusion, this study investigated the determinants of SMEs wealth creation in Nigeria, after examining 29 variables in regression test, the results show that the size and Age of the firms were significantly associated with wealth creation. The study tested empirically the wealth creation model of human resource, technology, innovation and creativity, unit cost economies, organizational infrastructure and strategy domains. All the domains were found to be relevant as determinants of wealth creation. 
SMEs' Wealth Creation Model of an Emerging Economy

\section{References}

Adejugbe, M. (2002). Perspectives on Nigeria's Fledging Fourth Republic. Lagos, Nigeria: Malthouse Press Ltd.

Adekunle, B. (2013). Determinants of microenterprise performance in Nigeria. International Small Business Journal, 29(4): 360-373. http://dx.doi.org/10.1177/0266242610369751

Aigbokhan, B. E. (2000). Poverty, growth and inequality in Nigeria: A case study. African Economic Research Consortium Research Report, 102, 62.

Alia, Y. A. (2014). The effectiveness of small and medium enterprises adoption as a strategic option to solve unemployment problem in the Arab World, an example of Algeria. International Journal of Business and Social Science, 5(4): 161-171.

Alpkan, L.Yilmaz, C and Kaya. (2007). Market orientation and planning flexibility in SMEs performance implications and an empirical investigation. International Small Business Journal, 25(2):152-172. http://dx.doi.org/10.1177/0266242607074518

Alvarez, S. A. and Busenitz, L. W. (2001). The entrepreneurship of resource-based theory. Journal of Management, 27: 755-775.

Analoui, F. and Karami, A. (2003). Strategic management in small and medium enterprises. London: Thomson.

Aragon-Sanchez, A. and Sanchez-Marin, G. (2005). Strategic orientation, management characteristics and performance: A study of Spanish SMEs. Journal of Small Business Management, 43(3): 287-308. http://dx.doi.org/10.1111/j.1540-627X.2005.00138.x

Asikhia, O. U. and Jansen van Rensburg, M. (2015). SMEs wealth creation model: A conceptual development. African Journal of Hospitality, Tourism \& Leisure, 4(1): 1-19.

Asikhia, O.U. (2015). Wriggling out of Nigerian economic quagmire: The polytechnic option. Being a Convocation Lecture Delivered at the Lagos State Polytechnic on the 9th April 2015.

Asikhia, O. U. (2010). SMEs and poverty alleviation in Nigeria: Marketing resources and capabilities implications. New England Journal of Entrepreneurship,13(2): 57-70

Aslan, S. and Elci, H. (2009.) SMEs' rating system and process in Turkey according to the Basel II settlements. Eurasian Journal of Business and Economics 2(4): 77-94

Bakos, Y. J. (1991). A strategic analysis of electronic marketplaces. MIS Quarterly, 15(3): 294310. http://dx.doi.org/10.2307/249641

Bamford, C. E., Dean, T. J. and McDougall, P. P. (1997). Initial Strategies and New Venture Growth: an Examination of the Effectiveness of Broad vs. Narrow Breadth Strategies. Frontiers of Entrepreneurship Research, 3: 75-87.

Barbero, J. L, Casillas, J. C and Feldman, H. D. (2011). Managerial Capabilities and Paths to Growth as Determinants of High-growth Small and Medium-sized Enterprises. International Small Business Journal, 29: 671-694. http://dx.doi.org/10.1177/0266242610378287

Barney, J. B. and Hesterley, W. S. (2006). Strategic Management and Competitive Advantage Concepts. New Jersey: Pearson Prentice Hall.

Barney, J. B. (1991). Firm resources and sustained competitive advantage. Journal of Management, 17: 99-120. http://dx.doi.org/10.1177/014920639101700108

Basco, R. (2014). Exploring the influence of the family upon firm performance: Does strategic behaviour matter? International Small Business Journal, 32(8): 967-995. http://dx.doi.org/10.1177/0266242613484946 
Batra, S., Sharma, S., Dixit, M. R and Vohra, N. (2015). Strategic orientations and innovation in resource-constrained SMEs of an emerging economy. Journal of Entrepreneurship, 24:1736. http://dx.doi.org/10.1177/0971355714560052

Bello, B. and Ivanov, S. (2014). Growth strategies for very small organizations: A case study of a very small entrepreneurship. The International Journal of Organizational Innovation, 6(4): 51-53.

Bharadwai, S. and Menon, A. (2000). Making Innovation Happen in Organizations: Individual Creativity Mechanisms, Organizational Creativity Mechanism or both? Journal of Production and Innovation Management, 17(4): 24-34.

Bullock, A. (2003). Survey design, response bias and sample characteristics in the 2002 CBR SME survey, in Enterprise Challenged: Policy and Performance in the British SMEs Sector, 1999-2002. Ed. Cosh, A. and Hughes, A. Cambridge: ESRC Centre for Business Research, 114127.

Camelo-Ordaz, C., Fernandez-Alles, M., Ruiz-Navarro, J. and Sousa-Ginel, E. (2012). The entrepreneur and innovation in creative firms. International Small Business Journal, 30(5): 513-535. http://dx.doi.org/10.1177/0266242610385396

Casillas, J. C. and Moreno, A. M. (2010). The Relationship between Entrepreneurial Orientation and Growth: The moderating role of Family Involvement. Entrepreneurship and Regional Development, 22: 265-291. http://dx.doi.org/10.1080/08985621003726135

Central Bank of Nigeria. (2012). Bullentin. Ikeja : Longman

Chang, Y. C., Chen, M. H., Lin Y. P and Gao, Y. S. (2012). Measuring regional innovation and entrepreneurship capabilities: The case of Taiwan science parks. Journal of Knowledge Economics, 3: 90-108. http://dx.doi.org/10.1007/s13132-011-0081-4

Chetty, S. K. and Wilson, H. (2003). Collaborating with competitors to acquire resources. International Business Review, 12: 61-81. http://dx.doi.org/10.1016/S0969-5931(02)00088-4

Chirico, F. (2008). Knowledge accumulation in family firms: Evidence from four case studies. International Small Business Journal, 26(4): 433-462.

http://dx.doi.org/10.1177/0266242608091173

Clark, K. (1996). Competing through manufacturing and the new manufacturing paradigm: Is manufacturing strategic passé. Production and Operations Management, 5(1): 42-58. http://dx.doi.org/10.1111/j.1937-5956.1996.tb00384.x

Cohen, W. M. and Levinthal, D. A. (1990). Absorptive capacity: A new perspective on learning and innovation. Administrative Science Quarterly, 35: 128-152. http://dx.doi.org/10.2307/2393553

Covin, J. G. and Slevin, D. P. (1991). A conceptual model of entrepreneurship as firm behavior. Entrepreneurship Theory and Practice, 16:7-25.

De Clercq, D. and Arenius, P. (2006). Technology adoption: The role of knowledge in business start-up activity. International Small Business Journal, 24(4): 339-358. http://dx.doi.org/10.1177/0266242606065507

De Clerca, D., Dimoy, N. and Thongpapanl, D. (2015). Structural and relational interdependence and entrepreneurial orientation in small and medium-sized enterprises: The mediating role of internal knowledge-sharing. International Small Business Journal, 33(5): 514-536. 
De Jong, J. P.J. and Vermeulen, P. A. M. (2006). Determinants of product innovation in small firms: A comparison across industries. International Small Business Journal, 24: 587-609. http://dx.doi.org/10.1177/0266242606069268

Devins, D. and Johnson, S. (2003). Training and development activities in SMEs. International Small Business Journal, 21 (2): 213-228. http://dx.doi.org/10.1177/0266242603021002005

Dugguh, S. I. (2013). Innovation and business success in Nigeria: From intuition to process Management. International Journal of Economics, Commerce and Management, 1(1): 1-8.

Emordi, E. (2008). Nigerian Economy under the Military 1985-1999: Implications for National Security' Paper Presented at the 53rd Annual Congress of the Historical Society of Nigeria, Gombe State University, Gombe, 13th -15th October, 2008

Enderle, G. (2005). 'Understanding of "Value-free" Business in the West,' in The Blackwell Encyclopedia of Management. Ed. Werhane, P. H. and Freeman, R. E. Business Ethics. Blackwell. : Malden, MA, 76-80.

Escriba-Esteve, A., Sanchez-Peinado, L. and Sanchez-Peinado, E. (2008). Moderating influences on the firm's strategic orientation-performance relationship. International Small Business Journal, 26(4): 463-489. http://dx.doi.org/10.1177/0266242608091174

Frazer, G. (2005). Which firms die? A look at manufacturing firm exit in Ghana. Economic Development and Cultural Change, 53(3): 585-617. http://dx.doi.org/10.1086/427246

Freel, M.S and Robson, P.J.A (2004). Small firm innovation, growth and performance: Evidence from Scotland and Northern England. International Small Business Journal, 22: 561-575. http://dx.doi.org/10.1177/0266242604047410

Gallego, J., Rubalcaba, L and Hipp, C. (2013). Organizational innovation in small European firms: A multidimensional approach. International Small Business Journal, 31: 563-579. http://dx.doi.org/10.1177/0266242611430100

Garavan, T., Watson, S., Carbery, R. and O'Brien, F.(2015). The antecedents of leadership development practices in SMEs: The influence of HRM strategy and practice. International Small Business Journal, http://dx.doi.org/10.1177/0266242615594215

Garfamy, R. M. (2012). Supply management: A transaction cost economics framework. South East European Journal of Economics and Business, 7(2):139-147. http://dx.doi.org/10.2478/v10033-012-0022-6

Gassmann, O. and Keupp. M. M. (2007). The competitive advantage of early and rapidly internationalizing SMEs in the biotechnology industry: A knowledge-based view. Journal of World Business, 42: 350-366. http://dx.doi.org/10.1016/j.jwb.2007.04.006

Goedhuys, M. and Sleuwaegen, L. (2010). High-growth entrepreneurial firms in Africa: A quantile regression approach. Small Business Economics, 34: 31-51.

http://dx.doi.org/10.1007/s11187-009-9193-7

Grant, R. M. (1996a). Prospering in dynamically-competitive environments: Organizational capability as knowledge integration. Organization Science, 7: 375-387. http://dx.doi.org/10.1287/orsc.7.4.375

Grant, R. M. (1996b). Towards a knowledge-based theory of the firm. Strategic Management Journals, 17:109-122. http://dx.doi.org/10.1002/smj.4250171110

Gray, G.T. and Gray, S.W. (2012). Marketing entrepreneurship: Linking alertness to entrepreneurial opportunities with strategic orientations. Journal of Marketing Development and Competitiveness, 6(3): 105-119. 
Hadjimanolis, A. and Dickson, K. (2000). Innovation and creativity: Innovation strategies of SMEs in Cyprus, a small developing Country. International Small Business Journal,18 (4): $62-$ 79. http://dx.doi.org/10.1177/0266242600184004

Hamilton, R. T. (2012). How firms grow and the influence of size and age. International Small Business Journal, 29(3): 278-294. http://dx.doi.org/10.1177/0266242610383446

Hilmersson, M. (2014). Experiential knowledge types and profiles of internationalising small and medium-sized enterprises. International Small Business Journal, 32 (7): 802-817, http://dx.doi.org/10.1177/0266242612458443

Hornsby, J.S. and Kuratko, D. F. (2003). Human resource management in U.S. small business: A replication and extension. Journal of Developmental Entrepreneurship, 8 (1): 73-92.

Illueca, M. and Lafuente, J. A. (2003). Unit cost economies: Productivity and scale effect in closely related firms: Evidence from the Spanish tile sector. International Small Business Journal, 21: 161-180, http://dx.doi.org/10.1177/0266242603021002002

Ireland, R. D., and Webb, J. W. (2007). Strategic entrepreneurship: Creating competitive advantage through streams of innovation. Business Horizons, 50: 49-59. http://dx.doi.org/10.1016/j.bushor.2006.06.002

Ireland, R. D., Hitt, M. A. and Simon, D. G. (2003). A model of strategic entrepreneurship: The construct and its dimensions. Journal of Management, 29 (6): 63-89. http://dx.doi.org/10.1016/S0149-2063(03)00086-2

Jain, R., and Ali, S.W. (2012). Entrepreneurial Motives of Indian Entrepreneurs: An Empirical Study, Indian Journal of Industrial Relations, 48, 1: 59-78

Jansen, R. J. G., Curseu, P. L., Vermeulen, P.A.M., Geurts, J. L. A. and Gibcus, P. (2013). Information processing and strategic decision-making in small and medium-sized enterprises: The role of human and social capital in attaining decision effectiveness. International Small Business Journal, 31(2): 192-216. http://dx.doi.org/10.1177/0266242611406762

Jaquier, B. (2003). Differentiation Strategy, Ecofine.com viewed. Retrieved from http://www.ecofine.com/strategy/Differenciation\%20stategy.htm. On 17/7/2015

Jayawarna, D., Jones, O. and Macpherson, A. (2014). Entrepreneurial potential: The role of human and cultural capitals. International Small Business Journal, 32(8): 918-943, http://dx.doi.org/10.1177/0266242614525795

Kalantaridis, C. (2009). Strategy: SME strategy, embeddedness and performance in East Cleveland, North East England. International Small Business Journal, 27(4): 496-521. http://dx.doi.org/10.1177/0266242609335019

Kiggundu, M. N. (2002). Entrepreneurs and entrepreneurship in Africa: What is known and what needs to be done. Journal of Developmental Entrepreneurship, 7(3): 239-258.

Kraus, S., Kauranen, I. and Carl, H. R. (2011). Identification of domains for a new conceptual model of strategic entrepreneurship using the Configuration Approach. Management Research Review, 34 (1): 58-74. http://dx.doi.org/10.1108/01409171111096478

Kyrgidou, L. (2008). Organizing and Benefiting from Strategic Entrepreneurship: The Role of Firm Resources, Capabilities and Internal Firm Conditions. Unpublished doctoral dissertation, Athens University of Economics and Business, Greece.

Liu, C., Teo, H., Oh, L.B, Wei, K.K. (2003). An empirical study of the effects of interactivity on web user attitude, International Journal of Human-Computer Studies, 58, 3: 281-305. 
Liu, X., Wright, M., Filatotchev, I. (2012). Opportunity evaluation and changing beliefs during the nascent entrepreneurial process, International Small Business Journal, 33: 612-637.

Love, J. H and Roper, S. (2015). SME innovation, exporting and growth: A review of existing evidence. International Small Business Journal, 33: 28-48.

http://dx.doi.org/10.1177/0266242614550190

Luke, B., Kearins, K. and Verreynne, M. L. (2011). Developing a conceptual framework of strategic entrepreneurshi. International Journal of Entrepreneurial Behaviour \& Research, 17(3): 314-337. http://dx.doi.org/10.1108/13552551111130736

Lukic, R. (2014). Analysis of the efficiency of small independent retailers in Serbia. Eurasian Journal of Business and Economics, 7(13): 91-103

Lumpkin, G. T. and Dess. G. G. (2001). Linking two dimensions of entrepreneurial orientation to firm performance: The moderating role of environment and industry life cycle. Journal of Business Venturing, 16: 429-451. http://dx.doi.org/10.1016/S0883-9026(00)00048-3

Majumdar, S. (2008). Modelling growth strategy in small entrepreneurial business organisations. The Journal of Entreprenuership, 17(2): 157-168. http://dx.doi.org/10.1177/097135570801700204

Makadok, R. (2001). Towards a Synthesis of the Resource-based and Dynamic-capability Views of Rent Creation. Strategic Management Journal, 22 (5), 387-402. http://dx.doi.org/10.1002/smj.158

Maney, I. M., Manoloya, T. S., Harkins, J.A. and Gyoshey, B.S. (2014). Are pure or hybrid strategies right for new ventures in transition economies? International Small Business Journal, doi: 10.1177/0266242614550322. http://dx.doi.org/10.1177/0266242614550322

Messeghem, K. (2003). Strategic entrepreneurship and managerial activities in SMEs. International Small Business Journal, 21: 197-212. http://dx.doi.org/10.1177/0266242603021002004

Minarik, M. (2007). Cost leadership and differentiation: An investigation of the fundamental trade-off between porter's cost leadership and differentiation strategies. MSc Thesis in International Business, Stockholm School of Business.

Nooteboom, B. (2007). Service value chains and effect of scale. Service Business, 1: 119-139. http://dx.doi.org/10.1007/s11628-006-0009-4

Obeng B. A., Robson, P. and Haugh, H. (2012). Strategic entrepreneurship and small firm growth in Ghana. International Small Business Journal .http://isb.sagepub.com/

O'Cass, A and Sok, P. (2014). The role of intellectual resources, product innovation capability, reputational resources and marketing capability combinations in firms' growth. International Small Business Journal, 32: 996-1018. http://dx.doi.org/10.1177/0266242613480225

Orewa, G. (2002). We Are All Guilty: The Nigerian Crisis. Ibadan: Spectrum Books Limited Pitelis, C.N. and Vasilaros, V. (2009). The determinants of value creation at the firm, industry and national levels: A framework and evidence. Dynamic Regions in a Knowledge-Driven Global Economy Lessons and Policy Implications for EU (DYNREG) Working Papers, 1-45

Porter, M. (1996). What is strategy? Harvard Business Review, 10(11): 60-80.

Rauch, A., Frese, M. and Utsch, A. (2005). Effects of human capital and long-term human resources development and utilization on employment growth of small-scale businesses: A causal analysis. Entrepreneurship Theory and Practice, 29 (6): 681-698. 
Ray, G., Barney, J. B. and Muhanna, W. A. (2004). Capabilities, business processes and competitive advantage: Choosing the dependent variable in empirical tests of the resource based view. Strategic Management Journal, 25 (1): 23-37.

Rayport, J. F and Sviokla, J. J. (1995). Exploiting the virtual value chain. Harvard Business Review, November/December, 75-85.

Rice, J., Liao, T., Galvin, P. and Martin, N. (2015). A Configuration-based approach to integrating dynamic capabilities and market transformation in small and medium-sized enterprises to achieve firm performance. International Small Business Journal, 33(3): 231253, doi: 10.1177/0266242613495035.

Robbins, S. (2000). Essential of Organization Behavior. Englewood Cliffs, NJ: Prentice-Hall.

Robson P. J. A. and Obeng, B. A. (2008). Barriers to growth in Ghana. Small Business Economics, 30(4): 385- 403.

Rosli, M. M. and Mahmood, R. (2013). Moderating effect of human resource practices and entrepreneur training on innovation and small-medium firms' performance, Journal of Management and Strategy, 4(2): 60-69.

Santos-Paulino, A. U. (2012). Trade, Income Distribution and Poverty in Developing countries: A survey. United Nations Conference on Trade and Development (UNITAD) Discussion Paper, 1-39.

Shaffer, P. (2008). New Thinking on Poverty: Implications for Globalization and Poverty Reduction Strategies. DESA Working Paper No. 65ST/ESA/2008/DWP/65 February, 2008.

Shaw, E. (2006). Small firm networking: An insight into contents and motivating factors. International Small Business Journal, 24(1): 5-29, doi: 10.1177/0266242606059777.

Skiltere, D. and Jesilevska, S. (2013). Building the system of innovation capability indicators: Case of Latvia. Eurasian Journal of Business and Economics 6(12): 113-128.

Spencer, A., Kirchhoff, B.A. and White, C. (2008). Entrepreneurship, innovation and wealth Distribution: The Essence of Creative Destruction. International Small Business Journal, 26(1): 9-26, doi: 10.1177/0266242607084657.

Teal, F. (1998). The Ghanaian Manufacturing Sector, 1991-1995: Firm Growth, Productivity and Convergence, WPS/98-17. Oxford, University of Oxford.

Teece, D. and Pisano, G. (1994). The dynamic capabilities of firms: An introduction. Industrial and Corporate Change, 3 (3): 537-556.

Thorgren, S. Wincent, J. and Ortgvist, D. (2012). Unleashing synergies in strategic networks of SMEs: The influence of partner fit on corporate entrepreneurship, International Small Business Journal, 30(5):453-471, doi: 10.1177/0266242610375292.

Tovar, B. and Wall, A. (2012). Economies of scale and scope in service firms with demand uncertainty: An application to a Spanish port, Maritime Economics \& Logistics, 14, 3: 362-385

Vyakarnam, S. and Handelberg, J. (2005). Four themes of the impact of management teams on organizational performance: Implications for future research of entrepreneurial teams. International Small Business Journal, 23(3):236-256, doi: 10.1177/0266242605052072.

Weick, K. E. (1976). Educational organizations as loosely coupled systems. Administrative Science Quarterly, 21 (3): 1-19.

Wernerfelt, B. (1995). The resource-based view of the firm: Ten years after, Strategic Management Journals, 16: 171-174. 
Whittaker, D. H., Fath, B. P and Fiedler, A. (2014). Assembling capabilities for innovation: Evidence from New Zealand SMEs. International Small Business Journal, doi: $10.1177 / 0266242614548931$.

Wilkerson, C. R. and Williams, M. D. (2011). Booms and busts in household wealth: Implications for tenth district states, Economic Review, Federal Reserve Bank of Kansas City, issue Q II.

World Bank. (1979). Attacking Poverty. World Development Report 2000/2001 New York: Oxford University Press.

Zahra, S. A. and George, G. (2002). Absorptive capacity: A review, reconceptualization and extension, Academy of Management Review, 27: 185-203.

Zhang, M., Macpherson, A. and Jones, O. (2006). Conceptualizing the learning process in SMEs improving innovation through external orientation, International Small Business Journal, 24(3): 299-323, doi: 10.1177/0266242606063434.

\section{Appendix}

\section{Table A.1. Factors loadings of the Construct}

\begin{tabular}{|c|c|c|c|c|}
\hline$S / N$ & \begin{tabular}{|l} 
Major \\
Variables
\end{tabular} & Sub-variables & \begin{tabular}{|c|} 
Internal \\
Consistency \\
\end{tabular} & $\begin{array}{l}\text { Composite } \\
\text { Reliability }\end{array}$ \\
\hline \multirow{5}{*}{1.} & \multirow{5}{*}{$\begin{array}{l}\text { Human } \\
\text { Resource }\end{array}$} & education & 0.83 & 0.84 \\
\hline & & Education & 0.81 & 0.83 \\
\hline & & Experience & 0.80 & 0.83 \\
\hline & & Abilities & 0.81 & 0.83 \\
\hline & & Skills & 0.82 & 0.84 \\
\hline \multirow{4}{*}{2.} & \multirow{4}{*}{ Technology } & \multirow{2}{*}{ Information acquisition } & 0.80 & 0.83 \\
\hline & & & 0.81 & 0.83 \\
\hline & & \multirow{2}{*}{ Information use } & 0.81 & 0.83 \\
\hline & & & 0.79 & 0.82 \\
\hline \multirow{4}{*}{3.} & \multirow{4}{*}{$\begin{array}{l}\text { Innovation \& } \\
\text { Creativity }\end{array}$} & Licensed intellectual property & 0.80 & 0.83 \\
\hline & & Customer Involvement & 0.81 & 0.83 \\
\hline & & Employee Involvement & 0.80 & 0.83 \\
\hline & & Network \& collaboration & 0.78 & 0.82 \\
\hline \multirow{2}{*}{4.} & \multirow{2}{*}{$\begin{array}{l}\text { Unit Cost } \\
\text { Economies }\end{array}$} & Economies scale & 0.79 & 0.82 \\
\hline & & Economies scope & 0.80 & 0.83 \\
\hline \multirow{4}{*}{5.} & \multirow{4}{*}{$\begin{array}{l}\text { Organisation } \\
\text { Infrastructure }\end{array}$} & Organization & 0.79 & 0.81 \\
\hline & & Flexibility & 0.80 & 0.82 \\
\hline & & Agility & 0.81 & 0.83 \\
\hline & & Degree of integration & 0.80 & 0.81 \\
\hline \multirow{6}{*}{6.} & \multirow{6}{*}{ Strategy } & Product differentiation & 0.78 & 0.80 \\
\hline & & Strategic entrepreneurship & 0.79 & 0.83 \\
\hline & & Opportunity selling & 0.79 & 0.82 \\
\hline & & Advantage seeking & 0.78 & 0.81 \\
\hline & & Niche Strategy & 0.80 & 0.82 \\
\hline & & \begin{tabular}{|l|} 
Cost parity \\
\end{tabular} & 0.79 & 0.81 \\
\hline
\end{tabular}

